\title{
Purification and Biochemical Characterization of Digestive Lipase in Whiteleg Shrimp
}

\author{
Crisalejandra Rivera-Pérez • \\ Fernando L. García-Carreño • Reinhard Saborowski
}

Received: 18 June 2009/Accepted: 25 April 2010

(C) Springer Science+Business Media, LLC 2010

\begin{abstract}
Penaeus vannamei lipase was purified from midgut gland of whiteleg shrimp. Pure lipase (E.C. 3.1.1.3) was obtained after Superdex 200 gel filtration and Resource Q anionic exchange. The pure lipase, which is a glycosylated molecule, is a monomer having a molecular mass of about $44.8 \mathrm{kDa}$, as determined by SDS-PAGE analysis. The lipase hydrolyses short and long-chain triacylglycerols and naphthol derivates at comparable rates. A specific activity of $1787 \mathrm{Umg}^{-1}$ and $475 \mathrm{Umg}^{-1}$ was measured with triolein and tributyrin as substrates, respectively, at $\mathrm{pH} 8.0$ and $30^{\circ} \mathrm{C}$ in the absence of colipase. The lipase showed a $K_{\mathrm{m} \text {, app }}$ of $3.22 \mathrm{mM}$ and $k_{\text {cat, app }} / K_{\mathrm{m} \text {, app }}$ of $0.303 \times 10^{3} \mathrm{mM}^{-1} \mathrm{~s}^{-1}$ using triolein as substrate. Natural detergents, such as sodium deoxycholate, act as potent inhibitors of the lipase. This inhibition can be reversed by adding fresh oil emulsion. Result with tetrahydrolipstatin, an irreversible inhibitor, suggests that the lipase is a serine enzyme. Peptide sequences of the lipase were determined and compared with the full-length sequence of lipase which was obtained by the rapid amplification of cDNA ends method. The full cDNA of the $p v l$ was $1,186 \mathrm{bp}$, with a deduced protein of 362 amino acids that includes a consensus sequence (GXSXG) of the lipase superfamily of $\alpha / \beta$-hydrolase. The gene exhibits features of conserved catalytic residues and high homology with various
\end{abstract}

C. Rivera-Pérez · F. L. García-Carreño $(\square)$

Centro de Investigaciones Biologicas del Noroeste (CIBNOR),

Apdo. Postal 128,

La Paz B.C.S. 23000, Mexico

e-mail: fgarcia@cibnor.mx

R. Saborowski

Alfred-Wegener-Institute für Polar- und Meeresforschung (AWI),

Biologische Anstalt Helgoland,

P.O. Box 180, 27483 Helgoland, Germany mammalian and insect lipase genes. A potential lid sequence is suggested for $p v l$.

Keywords Digestion - Lipase · Purification .

Penaeus vannamei $\cdot$ Crustaceans

\section{Introduction}

Lipases play an important role in lipid metabolism and energy homeostasis because fatty acids, mostly stored as triacylglycerides (TAG), are the major endogenous source of energy. In mammals, lysosomal and digestive lipases have been recognized by several authors (Roussel et al. 1999; Miled et al. 2000). Among digestive lipases, two major groups, gastric and pancreatic lipases, are of fundamental physiological interest because they are responsible for TAG hydrolysis (Miled et al. 2000). Studies of invertebrate lipid metabolism demonstrate lysosomal and digestive lipases (Arrese and Wells 1994; Slim et al. 2007).

Penaeid shrimp require food lipids to satisfy a variety of metabolic functions (González-Félix and Pérez-Velazquez 2002). Food lipid sources have been studied in penaeid species (González-Félix and Pérez-Velazquez 2002; Gonzalez-Baró and Pollero 1998). They demonstrate that shrimp have a limited ability to synthesize de novo the $n-6$ and $n-3$ highly unsaturated fatty acids. Lipids found in fish oils and plant oils rich in linoleic and linolenic acids are better utilized by crustaceans and have better nutritional value (Lim et al. 1997; González-Félix and Pérez-Velazquez 2002). The enzymes responsible for TAG hydrolysis from dietary lipids to free fatty acids are digestive lipases.

Lipases (EC 3.1.1.3) are characterized by the ability to hydrolyze hydrophobic long and short-chain glycerides (Jaeger et al. 1994). Lipases investigated so far vary 
considerably in size and in their primary structure; however, all of them belong to the $\alpha / \beta$-hydrolase superfamily, in which a nucleophilic serine amino acid residue is part of the catalytic triad (His, Ser, and Asp) and the consensus sequence (Gly-X-Ser-X-Gly). The active site of lipases is covered by a surface loop, named lid, which is displaced at the oil-water interface to permit the entry of hydrophobic substrates (Ollis et al. 1992).

To date, only a few studies are available about digestive lipases in crustaceans, their detailed function in lipid metabolism, and methods of purification and characterization. Lipases from crab Carcinus mediterraneus (Slim et al. 2007), scorpion Scorpio maurus (Zouari et al. 2005), and squid Todarodes pacificus (Park et al. 2008) have been purified. Some biochemical characteristics are similar to those found in mammalian digestive lipases: molecular masses of $\sim 40-50 \mathrm{kDa}$ with an alkaline $\mathrm{p} I$ between 6.8 and 7.8 (Moreau et al. 1992; Miled et al. 2000).

In crustaceans, lipases are liberated by B cells of the midgut gland (Loizzi and Peterson 1971) into the tubule lumen where they move into the gastric chamber and initiate lipid digestion of ingested food. Because TAGs are hydrophobic, some emulsifiers may be required. In Penaeidae, fat emulsifiers have not been described, but other decapods secrete acyltaurines for this purpose (Dall and Moriarty 1983). Moreover, mammalian pancreatic lipases require colipase, a pancreatic protein, as a cofactor for enzymatic activity (Lowe 1997). In contrast, in invertebrates, which lack a true liver, colipase has not been found, e.g., the crayfish Pacifastacus leniusculus (Marcus and Talalay 1956) and crab C. mediterraneus (Slim et al. 2007). Accordingly, there are marked differences between invertebrate and mammalian digestive lipases.

Lipases from different sources exhibit broad substrate specificities. Mammalian lipases exhibit a preference for short fatty acids and depend on bile salts and colipase (Holm et al. 2000). Crustaceans, such as the penaeids, Penaeus schmitti, Penaeus vannamei, Farfantepenaeus californiensis, and Farfantepenaeus notialis have a tendency to hydrolyze longer chain TAG, such as triolein, tripalmitin, and triestearin (Forrellat Barrios et al. 2004; Del Monte et al. 2002), show different enzymatic specificities, as well as different catalytic rates. Inhibitors, such as bile salts (Borgstrom and Donner 1976), are related to the change in the conformation of lipase during catalysis. However, only a few specific inhibitors have been identified, such as tetrahydrolipstatin and di-isopropyl fluorophosphate. These inhibitors are used to characterize digestive enzymes from the scorpion S. maurus (Zouari et al. 2005) and crab $C$. mediterraneus (Slim et al. 2007) as serine lipases.

To our knowledge, no digestive lipases were purified and sequenced from penaeids; hence, the details of the lipolytic process in crustaceans are still unknown. This is important in terms of better understanding of the nutrition and trophic interactions in the field. Moreover, lipolytic enzymes are valuable catalysts in many biotechnological applications. Therefore, novel enzymes from shrimps might exhibit catalytic properties that may be beneficial in biotechnological process. Here, we isolated and characterized a lipase from the midgut gland of $P$. vannamei to obtain the gene that codifies this protein.

\section{Materials and Methods}

Animals

Midgut gland tissue from whiteleg shrimp P. vannamei (= Litopenaeus vannamei) was obtained from aquaculture facilities. Midgut glands were dissected and immediately homogenized in cold, distilled water $(1: 4 w / v)$. The homogenates were centrifuged for $30 \mathrm{~min}$ at $10,000 \mathrm{~g}$ and at $4^{\circ} \mathrm{C}$. The supernatant was lyophilized and stored at $4{ }^{\circ} \mathrm{C}$ for further analysis.

\section{Determination of Lipase Activity and Protein Concentration}

Lipase activity was measured by titrating free fatty acids liberated from TAG at slightly alkaline conditions using the pH-stat standard assay conditions described by Gargouri et al. (1984). The reaction mixture consisted of $0.25 \mathrm{ml}$ triolein (Sigma, T-7140) in $30 \mathrm{ml}$ of $2.5 \mathrm{mM}$ Tris- $\mathrm{HCl}, 150 \mathrm{mM}$ $\mathrm{NaCl}$, and $3 \%$ gum arabic at $\mathrm{pH} 8.0$. The appropriate amount of enzyme was incubated at $30^{\circ} \mathrm{C}$ for $1 \mathrm{~h}$ with magnetic stirring. One activity unit corresponds to $1 \mu \mathrm{mol}$ fatty acids released per minute. Activity profiles of $\mathrm{pH}$, thermal stability, and inhibition were expressed in relation to the maximum value $(=100 \%)$ of the respective profile.

Lipase activity was also determined with a fluorescent substrate MUF-butyrate (Sigma, 19362). The substrate concentration in the assay was $100 \mu \mathrm{M}$ in a total volume of $300 \mu \mathrm{l}$ phosphate buffer $(50 \mathrm{mM}$, pH8.0). Fluorescence was measured at $355 \mathrm{~nm}$ (excitation) and $460 \mathrm{~nm}$ (emission) for 10 min with a fluorometer (Kontron SFM 25). Blanks were run in parallel. A standard curve was prepared with 4methylumbelliferone (Sigma, M1381). Activity profiles were expressed in relation to the maximum value $(=100 \%)$ of the respective profile. The protein concentration was determined using the Bradford method (1976). Bovine serum albumin (Sigma, B-4287) was used as a standard.

\section{Chromatography}

\section{Gel Filtration}

Lyophilized sample (200 $\mathrm{mg}$ ) was dissolved in $1 \mathrm{ml}$ PBS (50 mM phosphate, $150 \mathrm{mM} \mathrm{NaCl}, \mathrm{pH} 7.5$ ). Proteins from 
the midgut gland extract were separated by gel filtration chromatography using a FPLC system (Pharmacia Biotech, Uppsala, Sweden). Small proteins were removed by loading the sample onto a NAP- $10^{\mathrm{TM}}$ Sephadex G25 column (Amersham Biosciences, Uppsala, Sweden) and eluted with $1.5 \mathrm{ml}$ PBS buffer. The processed extracts were loaded into a 124-ml gel filtration column (HiLoad Superdex 200 16/60, Amersham Biosciences) equilibrated in PBS buffer. To separate the proteins by size, the column was washed with $175 \mathrm{ml}$ PBS buffer. Simultaneously, the absorbance at $280 \mathrm{~nm}$ and the conductivity were monitored and recorded. The flow rate was $1 \mathrm{ml} \mathrm{min}{ }^{-1}$. We collected 25 fractions of $5 \mathrm{ml}$ each. Each fraction was concentrated through centrifugal filters $\left(\right.$ AMICON $^{\circledR}$ Ultra-15, Millipore, Bellerica, MA, USA) at $4,000 \mathrm{~g}$ for $15 \mathrm{~min}$ as $25^{\circ} \mathrm{C}$ to a final volume of $500 \mu \mathrm{l}$.

\section{Anionic Exchange Chromatography}

Fractions with lipase activity from gel filtration were first loaded onto a NAP-5 ${ }^{\mathrm{TM}}$ column containing Sephadex G25 (Amersham Biosciences). The samples were eluted with the standard phosphate buffer (50 mM, pH8.0). Thereafter, the samples were loaded into a $1 \mathrm{ml}$ Resource Q column (Pharmacia Biotech) that was first equilibrated with the standard phosphate buffer. Under these conditions, the enzyme adsorbed onto the ionic support and was eluted with an increasing concentration of $\mathrm{NaCl}(0-1 \quad M)$ in standard phosphate buffer. Simultaneously, absorbance at $280 \mathrm{~nm}$ and conductivity were monitored and recorded. The flow rate was $1 \mathrm{ml} \mathrm{min}^{-1}$ and the final elution volume was $35 \mathrm{ml}$. Fractions of $500 \mu \mathrm{l}$ each were collected.

The fractions were assayed for lipase activity by MUFbutyrate hydrolysis: $10 \mu \mathrm{l}$ of each fraction were incubated at $30^{\circ} \mathrm{C}$ with $250 \mu \mathrm{l}$ MUF-butyrate at a final concentration of $100 \mu \mathrm{M}$. The assay was carried out as described above. The purified lipase (hereafter named PVL) was stored at $-80^{\circ} \mathrm{C}$ until further analysis.

\section{Mass Spectrometry Analysis}

To identify the pure enzyme, $3 \mu \mathrm{g}$ PVL were electrophoretically separated on a $12 \%$ acrylamide gel. After separation, the gel was stained with Coomassie Blue to identify protein bands that were cut from the gel. The sequence analysis was performed at the Wistar Institute Proteomics Facility using a trypsin digestion and nanocapillary HPLC interfaced directly with a hybrid ion trap mass spectrometer (Gel/LC-MS/MS).

\section{Electrophoresis}

Proteins bands were analyzed by electrophoresis under nonreducing as well as reducing conditions using SDS-
PAGE, as described by Laemmli (1970) and also by staining with silver nitrate (Merril and Washart 1998) in gels containing $12 \%$ acrylamide. For reducing conditions, samples were diluted $(1: 2)$ with sample buffer $(0.125 \mathrm{M}$ Tris-HCl, 2\% SDS, $20 \% v / v$ glycerol, $0.04 \%$ bromophenol blue, $5 \% \quad \beta$-mercaptoethanol at $\mathrm{pH} 6.8)$ and heated for $2 \mathrm{~min}$ at $100^{\circ} \mathrm{C}$. For nonreducing conditions, samples were mixed in the same buffer without mercaptoethanol and sodium dodecyl sulfate and were not heated. Electrophoretic separation was performed at $15 \mathrm{~mA}$ constant current and at $2{ }^{\circ} \mathrm{C}$. To detect protein bands, the gels were stained with $0.1 \%$ Coomassie brilliant blue R-250 in $7.5 \%$ acetic acid and 5\% methanol at room temperature and destained in $10 \%$ acetic acid and $40 \%$ methanol.

Zymograms were developed using MUF-butyrate as substrate (Prim et al. 2003). After electrophoretic separation of proteins, the gels were rinsed in water and then incubated at room temperature in Triton X-100 $(2.5 \% \mathrm{w} / \mathrm{v})$ for $30 \mathrm{~min}$. The gels were rinsed again with water and incubated in $100 \mathrm{ml}$ MUF-butyrate solution $(100 \mu \mathrm{M}$ dissolved in phosphate buffer, $50 \mathrm{mM}$ at $\mathrm{pH} 8.0$ ). After $10 \mathrm{~min}$, the fluorescence signal was detected and captured using a ChemiDoc XRS (Bio-Rad Laboratories, Hercules, CA, USA).

\section{Biochemical and Kinetic Characteristics}

\section{Isoelectric Focusing}

Analytical isoelectric focusing (IEF) was performed with the Phast System (Pharmacia Biotech, Uppsala, Sweden) using IEF gels at $\mathrm{pH}$ from 3 to 9 . A protein mixture (Broad $\mathrm{p} I$ 3.5-9.3) was used as the $\mathrm{p} I$ marker. The gel was treated with Coomassie brilliant blue R-250 using the method of Laemmli (1970).

\section{Glycosylation Analysis}

PVL was analyzed for glycosylation by electrophoresis under nonreducing conditions (Thornton et al. 1994). The gel was first incubated for $30 \mathrm{~min}$ at room temperature in solution $\mathrm{C}(50 \% v / v$ ethanol), rinsed with water, and thoroughly washed with distilled water for $10 \mathrm{~min}$. Then, the gel was incubated in solution A $(1 \% v / v$ periodic acid in $3 \% v / v$ acetic acid) for $30 \mathrm{~min}$, washed with distilled water for $30 \mathrm{~min}$, and washed for $20 \mathrm{~min}$ in solution B $(0.1 \% \mathrm{w} / \mathrm{v}$ sodium metabisulfite in $10 \mathrm{mM} \mathrm{HCl}$ ). Then the gel was incubated in Schiff's reagent for $1 \mathrm{~h}$ in the dark and immersed in solution B for $1 \mathrm{~h}$ in the dark. Finally, the gel was washed several times in solution $\mathrm{D}(0.5 \% \mathrm{w} / v$ sodium metabisulfite in $10 \mathrm{mM} \mathrm{HCl}$ ) for at least $2 \mathrm{~h}$ in the dark. The gel was stored in solution E $(7.5 \% v / v$ acetic acid, 5\% $v / v$ methanol). 


\section{The Effect of $p H$ and Temperature on Enzyme Activity}

The effect of $\mathrm{pH}$ on PVL activity was measured using $2 \mu \mathrm{g}$ lipase diluted in $15 \mu \mathrm{l}$ universal buffer at $37^{\circ} \mathrm{C}$ (Stauffer 1989). To obtain the required $\mathrm{pH}, 20 \mathrm{ml}$ stock solution (57 mM H $\mathrm{H}_{3} \mathrm{BO}_{3}, 36 \mathrm{mM}$ citric acid, $28 \mathrm{mM} \mathrm{NaH}_{2} \mathrm{PO}_{4}$, $310 \mathrm{ml} 1 \mathrm{~N} \mathrm{NaOH}$ ) was adjusted with $1 \mathrm{~N} \mathrm{HCl}$ and then filled up with distilled water to $100 \mathrm{ml}$. Buffers were prepared for the $\mathrm{pH}$ range from 2 to 12 . After incubation for $1 \mathrm{~h}$ at room temperature, lipase activity was assayed by titration using triolein as the substrate.

To measure the effect of temperature on PVL activity, $2 \mu \mathrm{g}$ lipase diluted in $15 \mu \mathrm{l}$ buffer ( $50 \mathrm{mM}$ Tris- $\mathrm{HCl} 50$, $\mathrm{pH}$ 8.0) were incubated for $1 \mathrm{~h}$ at temperatures ranging from $10^{\circ} \mathrm{C}$ to $80^{\circ} \mathrm{C}$. Immediately after incubation, lipase activity was measured by titration using triolein as the substrate.

\section{Substrate Specificity}

PVL substrate specificity was measured (Versaw et al. (1989) by assaying its hydrolytic activity on naphthyl derivates and triacylglycerols with different chain length: tributyrin (Sigma, T-8626), tripalmitin (Sigma, T-5888), tristearin (Sigma, T-5016), and triolein (Sigma, T-7140). Specific activity was determined spectrophotometrically for naphthyl derivates and $\mathrm{pH}$-stat titration as described for TAGs hydrolysis (Gargouri et al. 1984).

\section{Effect of $\mathrm{Ca}^{2+}$ Concentrations on Enzyme Activity}

The effect of $\mathrm{Ca}^{2+}$ on PVL was determined by measuring the hydrolytic activity of triolein in the presence of different calcium concentration $(0-100 \mathrm{mM} \mathrm{CaCl} 2)$ by the $\mathrm{pH}$-stat method.

\section{Effect of Inhibitors and Bile Salts on Enzyme Activity}

To determine if PVL is a serine lipase, tetrahydrolipstatin (THL, Sigma, O-4139) was used as a specific inhibitor. We used $0,2.5,5,7.5$, and $10 \mathrm{mM}$ THL to measure its effect on lipase activity. Equal volumes of inhibitor and enzyme solution $\left(0.2 \mathrm{mg} \mathrm{ml}^{-1}\right)$ were incubated for $1 \mathrm{~h}$ at room temperature, and the residual activity was measured by titration, as described above.

The effect of bile salt on PVL activity was measured with $0-4 \mathrm{mM}$ sodium deoxycholate $(\mathrm{NaDC}$, Sigma D$6750)$. Enzyme solution $\left(0.2 \mathrm{mg} \mathrm{ml}^{-1}\right)$ was added to a triolein substrate solution which contained NaDC. To restore PVL activity, fresh oil emulsion was added after 30 min of reaction.

\section{Kinetics Parameters}

The kinetic parameters $K_{\mathrm{m}}$, app and $V_{\max }$, app of PVL were measured using triolein and MUF-butyrate as substrates. Triolein hydrolysis was assayed at concentrations of 0 to $20 \mathrm{mM}$ during $1 \mathrm{~h}$ using the $\mathrm{pH}$-stat method. MUF-butyrate hydrolysis was assayed fluorometrically at concentration of 0 to $100 \mu \mathrm{M}$ for $10 \mu \mathrm{min}$. $K_{\mathrm{m}}$, app $(\mathrm{mM})$ and $V_{\max }$, app $\left(\mathrm{U} \mathrm{mg}^{-1}\right)$ with the Lineweaver-Burk transformation graph.

\section{Lipase cDNA Sequence}

To amplify the full-length cDNA of $P$. vannamei lipase gene $p v l$, a $5^{\prime} / 3^{\prime}$ rapid amplification of cDNA ends was performed (GeneRacer ${ }^{\mathrm{TM}}$ Kit, L1500, Life Technologies, Carlsbad, CA, USA). cDNA was prepared from $1 \mu \mathrm{g}$ total RNA isolated from midgut gland tissue using Trizol reagent (Life Technologies). The primers based on a partial sequence of lipase (GenBank accession no. DQ858927) were designed as follows: PvLip_F1 (5'-GAAAGCG CTGGCTTACAAAC-3') and PvLip_R1 (5'-TAGGAC CTTCGGCATTGTTC-3').

The synthesized primers were used as internal genespecific primers and $5^{\prime} / 3^{\prime}$ nested primers included in the GeneRacer ${ }^{\mathrm{TM}}$ Kit were used as anchors at the cDNA ends. PCR amplification was performed using GoTaq ${ }^{\circledR}$ Green Master Mix (Promega, M7122, Madison, WI, USA), primers (10 $\mu \mathrm{M}$ each), cDNA template $1 \mu \mathrm{l}$ (diluted 1:50), and nuclease-free water. All reactions were performed in a final volume of $25 \mu$ l. The thermal cycling program to amplify the lipase gene was performed on a thermocycler (Bio-Rad), configured as follows: 35 cycles of $1 \mathrm{~min}$ at $95^{\circ} \mathrm{C}, 30 \mathrm{~s}$ at $59^{\circ} \mathrm{C}$, and $1 \mathrm{~min}$ at $68^{\circ} \mathrm{C}$ followed by a single cycle at $72^{\circ} \mathrm{C}$ for $10 \mathrm{~min}$. PCR products were cloned (TOPO-TA cloning kit, Life Technologies K4500-01) and transformed into Escherichia coli DH $5 \alpha$. Database nucleotide homology searches were carried out using BLAST in at the National Center of Biotechnology Information (Altschul et al. 1997). Gene translation of the deduced protein was performed with ExPASy (Gasteiger et al. 2003), and alignments were performed with the ClustalW software (Thompson et al. 1994). The nucleotide sequence of lipase gene ( $p v l)$ was deposited in GenBank (accession no. FJ619564).

\section{Results}

Purification of Lipase

PVL was purified by the two-step procedure described in the methods section. After the first step, the gel filtration 
Fig. 1 Pure fraction from ion exchange chromatography. a The fractions showing lipase activity $(37-40)$ were collected. b The zymogram of fractions (37-40) using MUF-butyrate as the substrate. c Fractions containing pure Penaeus vannamei lipase, separated by SDS-PAGE $12 \%$ and stained with Coomassie brilliant blue R-250. d Zymogram using MUF-butyrate as the substrate. e Silver-stained gel showing a single isolated protein band

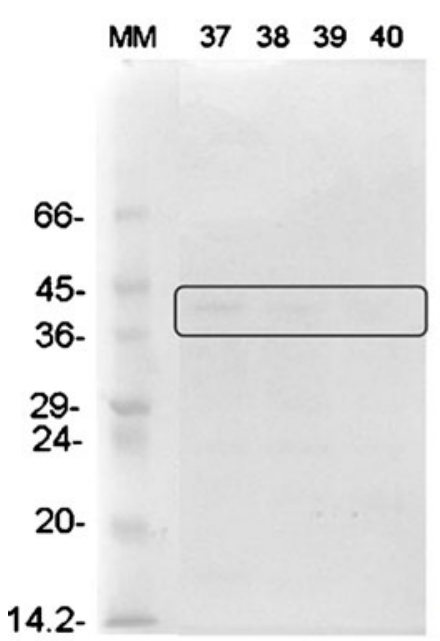

a)

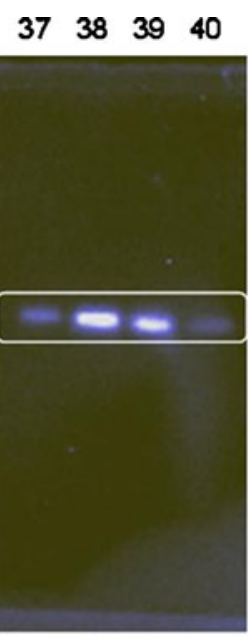

b)

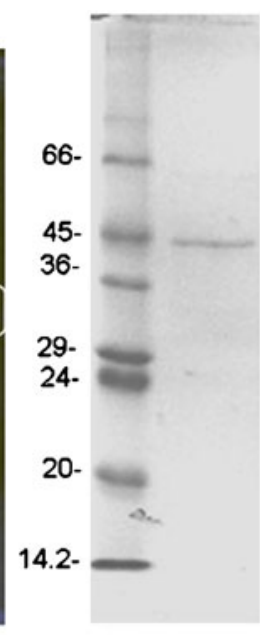

c)

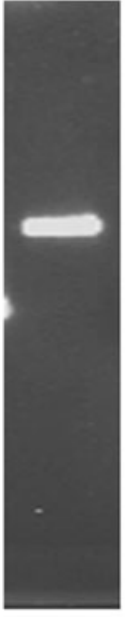

d)

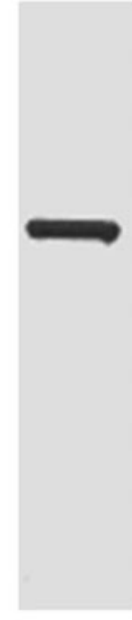

e) over a Superdex 200 column, the collected fractions contained different molecular weight proteins were revealed by SDS-PAGE and only those fractions containing PVL were subjected to anionic exchange chromatography on a Resource Q column. The fractions containing the eluted PVL (Fig. 1a, b) were pooled. A single band in SDS-PAGE (Fig. 1c), in zymogram analysis (Fig. 1d), and silver stain (Fig. 1e) was observed. A flow sheet of the purification process for PVL is presented in Table 1. The enzyme was enriched 48 -fold and the yield was $0.12 \%$. The apparent molecular mass of the band with lipase activity was $44.8 \mathrm{kDa}$ (Fig. 1c). Electrophoresis analysis of PVL under reducing conditions showed a single band, demonstrating that PVL is a monomeric protein, which is also glycosylated and has a $\mathrm{p} I$ of 3.5. The sequence analysis (Gel/LCMS/MS) results of PVL matched the deduced amino acid sequence of PVL.

\section{General Characteristics}

In whiteleg shrimp, PVL from the digestive system is capable of hydrolyzing naphthol esters, such as naphthyl acetate, and triacylglycerides, such as triolein. Four triacylglycerides were assayed to measure the specific activity of PVL. The pure enzyme shows $73 \%$ higher hydrolytic activity on long-chain triacylglycerols $\left(\mathrm{TC}_{18}\right)$ than on shorter triacylglycerols. The specific activity of $\mathrm{PVL}$ was $1787 \mathrm{Umg}^{-1}$ for $\mathrm{TC}_{18}$ and $475 \mathrm{Umg}^{-1}$ for $\mathrm{TC}_{4}$ at $\mathrm{pH} 8.0$ and $30^{\circ} \mathrm{C}$ (Table 2).

Preliminary experiments with PVL indicated that the enzyme had low phospholipase activity. To confirm that this activity was inherent to PVL rather than to a contaminant protein, a zymogram of PVL was performed using PED6 (Life Technologies, D-23739) as substrate and compared to MUF-butyrate zymogram (data not shown). The zymogram showed significantly higher hydrolyzing activity for MUF-butyrate than for PED6. Both activity bands had the same molecular weight of $44.8 \mathrm{kDa}$, confirming the enzyme responsible for the activity is PVL.

The effect of temperature on PVL activity was assayed over a range from $10^{\circ} \mathrm{C}$ to $80^{\circ} \mathrm{C}$ (Fig. 2a). Maximum activity under these conditions took place at $30^{\circ} \mathrm{C}$. Between $10^{\circ} \mathrm{C}$ and $20^{\circ} \mathrm{Cm}$, activity was less than $10 \%$. Above $40^{\circ} \mathrm{C}$, there was a continuous drop in PVL activity caused by denaturation.

Table 1 Summary of Penaeus vannamei lipase purification

\begin{tabular}{|c|c|c|c|c|c|}
\hline Step & Total protein (mg) & Total activity $(\mathrm{U})$ & Specific activity $\left(\mathrm{U} \mathrm{mg}^{-1}\right)$ & Purification (fold) & Yield $(\%)$ \\
\hline Freeze-drying & $197.6 \pm 2.5$ & $14,162 \pm 70.7$ & $71.6 \pm 0.65$ & 1 & 100 \\
\hline S-200 chromatography & $1.82 \pm 0.06$ & $2,285 \pm 4.08$ & $1,252 \pm 45.2$ & $17.46 \pm 0.47$ & $0.16 \pm 0.0$ \\
\hline Source 15 Q chromatography & $0.51 \pm 0.02$ & $1,783 \pm 5.11$ & $3,447 \pm 174$ & $48.12 \pm 2.8$ & $0.12 \pm 0.0$ \\
\hline
\end{tabular}

Protein concentration was estimated by the Bradford method. The experiments were conducted three times; standard errors are shown

1 unit $1 \mu \mathrm{mol}$ of fatty acid released per minute using $\mathrm{TC}_{18}$ 
Table 2 Lipase activity of Penaeus vannamei

\begin{tabular}{lc}
\hline Substrates & Specific activity $\left(\mathrm{Umg}^{-1}\right)$ \\
\hline Naphthyl ester & \\
$\alpha$-Naphthyl acetate & $429.5 \pm 2.3$ \\
$\beta$-Naphthyl acetate & $441.0 \pm 1.3$ \\
$\beta$-Naphthyl caprylate & $15.1 \pm 0.1$ \\
Triacylglycerides & \\
Tributyrin (C:4) & $475.8 \pm 4.9$ \\
Tripalmitin (C:16) & $661.0 \pm 9.8$ \\
Tristearin (C:18) & $780.6 \pm 9.8$ \\
Triolein (C18:1) & $1,787.3 \pm 7.9$ \\
\hline
\end{tabular}

The effect of $\mathrm{pH}$ on PVL is presented in Fig. 2b. PVL has a maximum activity on $\mathrm{TC}_{18}$ at $\mathrm{pH} 8.0$ to 9.0. PVL lost activity below $\mathrm{pH} 4.0$ and above $\mathrm{pH} 10.0$. After $2 \mathrm{~h}$ incubation, $60 \%$ of activity of PVL was lost at pH10.0. PVL does not rely on calcium for activity (data not shown).

\section{Kinetic Parameters}

There are only a few reports describing kinetic parameters of lipase in invertebrates. Triolein and MUF-butyrate were used as substrates under optimal conditions $\left(\mathrm{pH} 8.0\right.$ and $30^{\circ} \mathrm{C}$ ). The kinetic values of PVL were obtained using the Michaelis-Menten model. Catalytic properties of PVL were $K_{\mathrm{m} \text {, app }}=3.22 \mathrm{mM}$ and $V_{\max , \text { app }}=3404 \mathrm{Umg}^{-1}$ for triolein and $0.24 \mathrm{mM}$ and $3042 \mathrm{Umg}^{-1}$ for MUF-butyrate (Table 3).

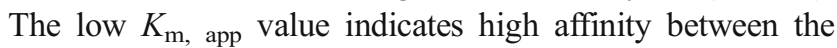
enzyme and the substrate. PVL showed $>150$-fold higher catalytic efficiency $\left(k_{\text {cat, app }} / K_{\mathrm{m} \text {, app }}=52.8 \times 10^{3} \mathrm{mM}^{-1} \mathrm{~s}^{-1}\right)$ for MUF-butyrate than for triolein $\left(0.303 \times 10^{3} \mathrm{mM}^{-1} \mathrm{~s}^{-1}\right)$. The higher catalytic efficiency of PVL on MUF-butyrate is related to higher affinity for this substrate.

\section{Colipase and Effect of Bile Salts on PVL Activity}

To corroborate that shrimp cosynthesize a colipase as a cofactor for PVL, a crude extract of midgut gland was treated for $30 \mathrm{~min}$ at $\mathrm{pH} 4.0$ and $65^{\circ} \mathrm{C}$ to denature lipase, but preserving colipase activity (Slim et al. 2007). At the same time, porcine lipase (Lipase type II, Sigma, L-3126), used as a control, was inhibited with $3 \mathrm{mM} \mathrm{NaDC}$ and the reactivation was tried by mixing the putative colipase from whiteleg shrimp with the inhibited porcine lipase in the same reaction mixture containing triolein as substrate; the hydrolysis of triolein was measured by $\mathrm{pH}$-stat. There was no reactivation of porcine lipase (data not shown), so, under the conditions used here, we concluded that shrimp do not possess colipase as a cofactor of PVL.

The effect of increasing concentrations of bile salt (NaDC) on the rate of hydrolysis of $\mathrm{TC}_{18}$ by PVL is shown in Fig. 3a. When $\mathrm{NaDC}$ was placed at the water/ lipid interface, below the critical micellar concentration (the concentration of surfactant above where micelles are formed), the apparent activity of lipase decreased to $40 \%$ of the initial activity with $1 \mathrm{mM}$ of $\mathrm{NaDC}$. This inactivation is related to the critical concentration of $\mathrm{NaDC}$ in the micelle $(5 \mathrm{mM})$, which may shift downward in the presence of a water-lipid interface, which results from adsorption of detergent molecules (Hermoso et al. 1996). This effect was observed in PVL when a fresh emulsion of triolein was added after $30 \mathrm{~min}$ of reaction (Fig. 3a).

\section{Effect of Inhibitors on Enzyme Activity}

THL is a specific inhibitor of lipases (Gargouri et al. 1991), which react with the catalytic serine of active site. To determine if the active site of PVL contains a serine, we assayed the effect of THL on PVL activity (Fig. 3b). PVL lost $95 \%$ of its activity when incubated with $2.5 \mathrm{mM}$ THL, demonstrating that PVL is a serine lipase, which agrees with the deduced amino acid sequence obtained, including the consensus sequence GXSXG.

\section{Lipase cDNA Sequence}

The full cDNA encoding triacylglycerol lipase $p v l$ from the midgut gland of whiteleg shrimp was uploaded from the
Fig. 2 The effect of a temperature and $\mathbf{b} \mathrm{pH}$ on PVL using TC18 by the titrimetric method. The activities were calculated in relation to the mean of all measurements which was set to be $100 \%$ (means $\pm \mathrm{SD}, n=3$ )
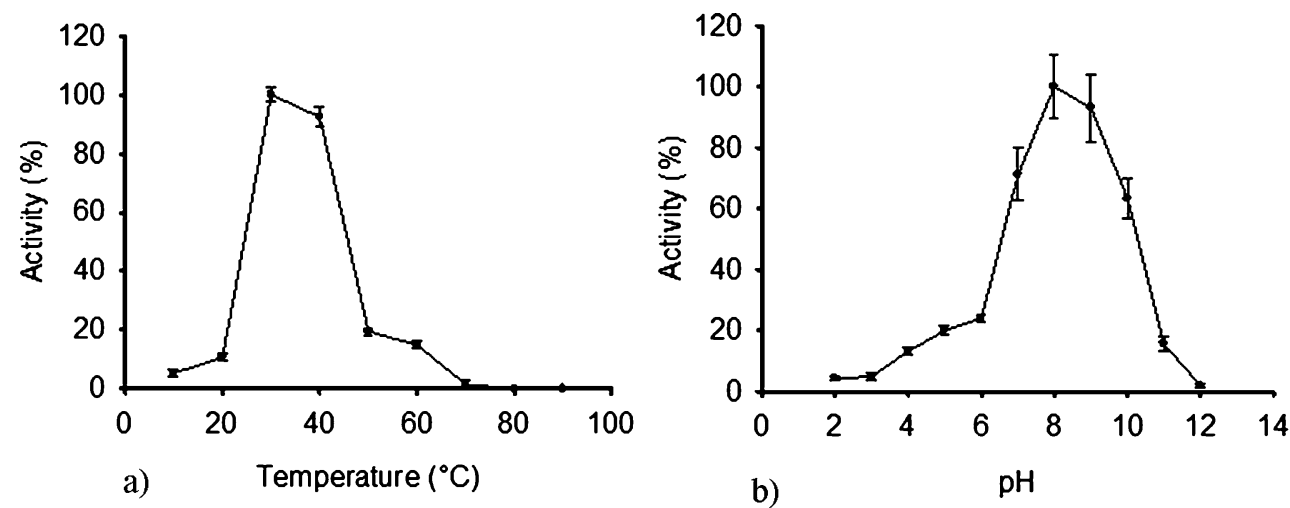
Table 3 Kinetic values of Penaeus vannamei lipase

\begin{tabular}{lllcc}
\hline Substrate & $V_{\max }\left(\mathrm{Umg}^{-1}\right)$ & $K_{\mathrm{m}}(\mathrm{mM})$ & $k_{\mathrm{cat}}\left(\times 10^{3} \mathrm{~s}^{-1}\right)$ & $k_{\mathrm{cat}} / K_{\mathrm{m}}\left(\times 10^{3} \mathrm{mM}^{-1} \mathrm{~s}^{-1}\right)$ \\
\hline $\mathrm{TC}_{18}$ & $3,404 \pm 29.51$ & $3.22 \pm 0.12$ & $1.01 \pm 0.04$ & $0.303 \pm 0.02$ \\
MUF-butyrate & $3,042 \pm 2.88$ & $0.24 \pm 0.00$ & $12.67 \pm 0.27$ & $52.8 \pm 2.33$ \\
\hline
\end{tabular}

GenBank database (GenBank accession no. FJ619564). We obtained a 335-bp fragment of DNA with specific primers (PvLip_F1 and PvLip_R1), a 242 bp 5' end fragment and a $609 \mathrm{bp} 3^{\prime}$ end fragment with a polyadenylation $(\mathrm{A})^{+}$tail. We obtained a 1,186-bp full-length cDNA using overlapping PCR that included a 59-bp $5^{\prime}$ untranslated region and a 1,089-bp open reading frame (ORF). The $3^{\prime}$ end contained a $20-\mathrm{bp}$ polyadenylation $(\mathrm{A})^{+}$tail that was $14 \mathrm{bp}$ from ATAA, the eukaryotic consensus polyadenylation signal. The ORF encoding a 362-amino acid protein was $41.2 \mathrm{kDa}$ and a putative isoelectric point of 4.7. The protein included a consensus sequence composed of GXSXG and a catalytic triad composed of Ser, Asp, and His (Fig. 4). The lid domain was recognized by comparing the aligned sequence of invertebrate and mammal lipases between residues 219-241 of PVL (Table 4). BLASTX analysis demonstrated that $45 \%$ of the sequence of $p v l$ is identical to the amino acid sequence of $A$. aegypti lipase $1,46 \%$ of Culex quinquefasciatus lipase 1, 42\% of Ixodes scapularis triacylglycerol lipase, and $40 \%$ of Drosophila melanogaster lip4; these lipases showed amino acid residues of the active site at homologous positions (Fig. 5). The deduced amino acid sequence of $p v l$ coincides with the four peptide sequences obtained by mass spectrometric procedures. The pattern [DY] [L] [G] XXX [VYY] X [GXSXGX] was identified as part of the amino acid sequences of PVL that corresponds to a $\alpha / \beta$-hydrolase structure (Fig. 4) of this kind of enzyme.

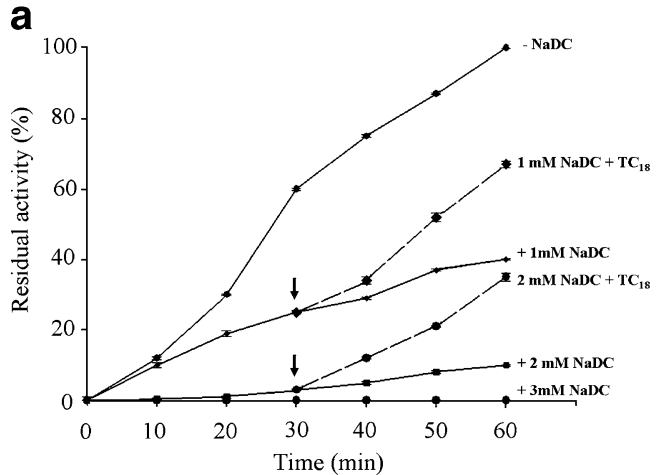

Fig. 3 The effect of bile salts and inhibitors on PVL. a The effect of increasing the concentration of bile salts $(\mathrm{NaDC})$ on the rate of hydrolysis of TC18 by Penaeus vannamei lipase. b Effect of increasing concentration of THL on the rate of hydrolysis of TC18 by Penaeus vannamei lipase. Lipase activity was measured at $\mathrm{pH} 8.0$

\section{Discussion}

This is the first detailed report of the purification of a lipase from the midgut gland of whiteleg shrimp. The lipase is a glycoprotein with a molecular mass of $44.8 \mathrm{kDa}$, which is similar to that for other lipases from the redclaw crayfish Cherax quadricarinatus (López-López et al. 2003), squid Ommastrephes bartramii (Sukarno et al. 1996), and scorpion S. maurus (Zouari et al. 2005). Within the conserved domain identified in the deduced amino acid sequence of $p v l$, a catalytic triad and a lid were identified, which shared similarity in residues to those seen in other lipases, and the level of similarity seen here and the catalytic properties of the pure lipase supports $p v l$ encoding a lipase protein with novel biotechnological applications.

Glycosylation in PVL is a usual feature of lipases (Buscá et al. 1995). Other glycosylated lipases have been described in invertebrates such as the scorpion S. maurus (Zouari et al. 2005). However, lipases shown a different degree of glycosylation which differs among species (Rathelot et al. 1981). The carbohydrate portion of PVL could play a functional role in controlling its secretion by B cells, as in mammals, in which the main role of glycosylation have been attributed to the control of secretion of the protein and stability (Buscá et al. 1995). The nature of the carbohydrate and its functional role in PVL remains to be investigated.

Besides other factors, activity and stability of an enzyme are functions of temperature and $\mathrm{pH}$. In whiteleg shrimp,

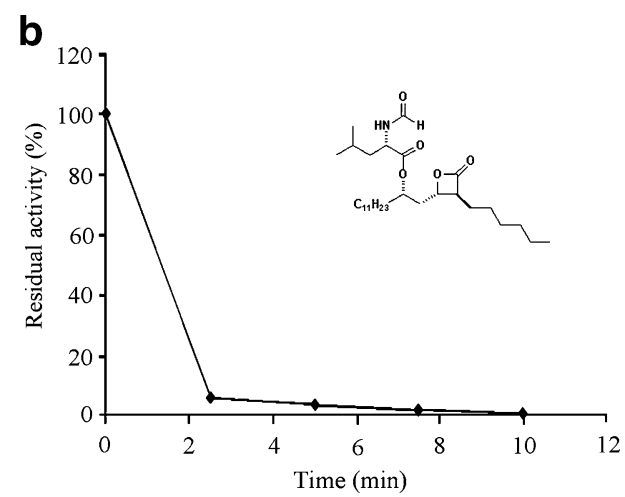

and $30^{\circ} \mathrm{C}$ using $\mathrm{TC} 18$ as the substrate. The arrows indicate the addition of TC18 fresh emulsion. The activities were calculated in relation to the mean of all measurements which was set to be $100 \%$ (means $\pm \mathrm{SD}, n=3$ ) 
Fig. 4 Nucleotide and deduced amino acid sequence of Penaeus vannamei lipase cDNA

(GenBank accession no.

FJ619564). Consensus sequence

(GXSXG) is shaded in gray.

Residues of catalytic (shaded triangle) and pattern of $\alpha / \beta$-hydrolase structure (asterisk) are indicated. The peptide sequences obtained by mass spectrometry are boxed. Underlining in the nucleotide sequence indicates polyadenylation

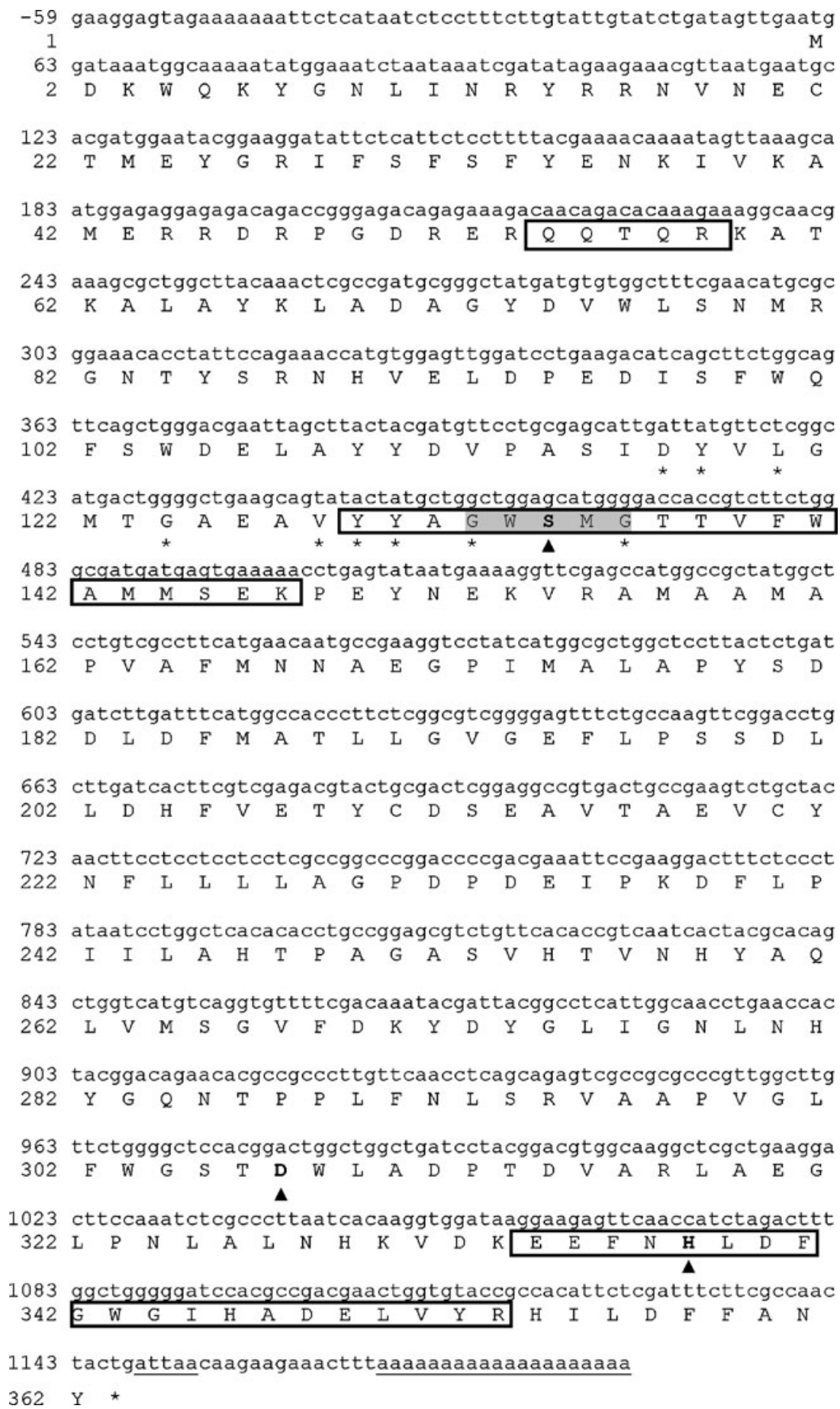

$90 \%$ of lipase activity occurs in a range of $30-40^{\circ} \mathrm{C}$. Temperatures of maximum lipase activity in other organisms are also quite narrow. Digestive lipase of the neon fly squid $O$. bartramii, displays its highest activity between $30-40^{\circ} \mathrm{C}$ (Sukarno et al. 1996) and in the Indian fish, the rohu Labeo rohita at $45^{\circ} \mathrm{C}$ (Nayak et al. 2004). The crab $C$. mediterraneus exhibits maximum lipase activity at $60^{\circ} \mathrm{C}$ (Slim et al. 2007), while activity in whiteleg shrimp lipase decreases above $40^{\circ} \mathrm{C}$.
The $\mathrm{pH}$ range over which an enzyme will be stable varies from one protein to another; lipase from whiteleg shrimp has maximum activity from $\mathrm{pH} 7$ to 8 . The $\mathrm{pH}$ for maximum activity of digestive lipases in the scorpion is between 8.5 and 9 (Zouari et al. 2005), which is related to the ionization properties of histidine $(\mathrm{pKa}=6.5)$ and the fact that the amino acid residues of the catalytic triad (Ser, His and Asp) (Roussel et al. 1999) play an important role in the charge relay system involving the catalytic triad and the 
Table 4 Sequence alignment of endothelial, hepatic, lipoprotein, and Penaeus vannamei lipase lid region

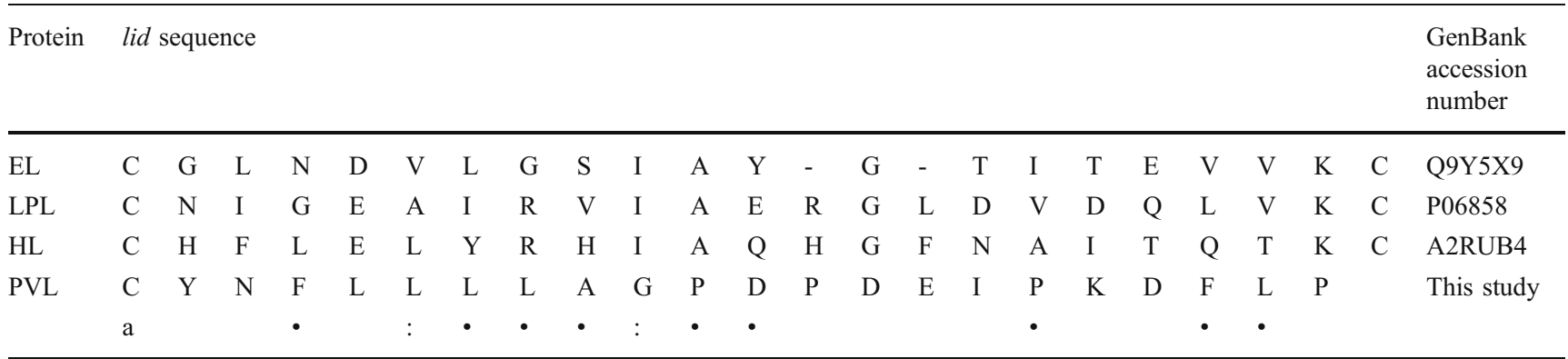

a highly conserved amino acid, $\bullet$ and : semiconservative amino acid replacement

enhancement of the nucleophilic character of the serine residue. Digestive lipases from organisms other than crustaceans also have maximum activity in the alkaline range of the $\mathrm{pH}$ scale: bovine pancreatic lipase, $\mathrm{pH}$ 8 (Shahani et al. 1976), human hepatic lipase, pH 8 (De Caro et al. 1977), and the bacterium Mycobacterium tuberculosis, pH 8-9 (Deb et al. 2006). PVL lost activity below $\mathrm{pH} 4.0$ and above $\mathrm{pH} 10$. After $2 \mathrm{~h}$ of incubation, $60 \%$ of activity of PVL was lost at $\mathrm{pH} 10$. Lipase of scorpion $S$. maurus lost only $35 \%$ of its activity after $4 \mathrm{~h}$ incubation at $\mathrm{pH} 11$ and $\mathrm{pH}$ under 5 (Zouari et al. 2005), as well as lipase from the Asian gypsy moth Lymantria dispar (Mrdakovic et al. 2008) and squid O. bartramii (Sukarno et al. 1996). Lipase activity decreased in Rodnius prolixus and Cephaloleia presignis at $\mathrm{pH}>8.0$ (Arreguín-Espinosa et al. 2000; Grillo et al. 2007); these evidences showed that the $\mathrm{pH}$ stability of lipases differs between species.

Cationic cofactors are required for lipase activity of vertebrates. Divalent cations, such as calcium, increase enzyme activity. For example, maximum lipase activity in adipose tissue of pig occurs at $10 \mathrm{mM} \mathrm{CaCl}_{2}$ (Matsumura et al. 1976). PVL does not rely on calcium for activity, indicating that PVL catalytic properties are dissimilar to mammalian lipases. This is supported by reports showing that lipase in insects $R$. prolixus (Grillo et al. 2007) and $C$. presignis (Arreguín-Espinosa et al. 2000) have the same activity regardless of the calcium concentration. To date, it is not certain that invertebrate digestive lipases require a moderate concentration of calcium for activity or stability, as observed in mammalian digestive lipases.

The pure shrimp lipase shows properties of serine lipases. It is inhibited by THL, which is consistent with the presence of serine at the catalytic site. This result is consistent with the consensus sequence GXSXG obtained from shrimp lipase cDNA which characterizes the lipase gene family which is composed by pancreatic, lipoprotein, and hepatic lipases, based on amino acid sequence similarity (Hide et al. 1992), confirming its identity.
In spite of the absence of a true liver in invertebrates, emulsifiers such as NaDC act as an inhibitor of PVL; its inactivation may be shifted downward, as are mammalian lipases. This evidence suggests similar structural properties with the vertebrate lipases. However, the lack of colipase in invertebrates such as shrimp, we suggest that colipase and bile salts evolved after the divergence of invertebrate and vertebrate.

The feeding behavior of marine invertebrates has been described for some organisms. There are differences in feeding behavior among penaeids and among the stages of their development. The use of different lipids, such as TAG, as sources of energy may depend on its digestibility, energy content, and fatty acid composition.

PVL was able to hydrolyze long-chain TAG better than short ones, in contrast to crab digestive lipase with $500 \mathrm{U}$ $\mathrm{mg}^{-1}$ for $\mathrm{TC}_{4}$ and $130 \mathrm{Umg}^{-1}$ for olive oil (Slim et al. 2007). The tendency of PVL to hydrolyze long-chain TAG is similar to other shrimp lipases (Del Monte et al. 2002; Forrellat Barrios et al. 2004) and could be related to hydrophobicity of the PVL lid (residues 219-241), which differ from those of mammalian lipases, such as human endothelial lipase, lipoprotein lipase, and hepatic lipase (Table 3). In previous work done on lipoprotein and hepatic lipase in humans, it (Dugi et al. 1995) found that the sequence of the lids and its hydrophobicity affect enzymatic activity. The capability of whiteleg shrimp to hydrolyze long-chain TAG from alimentary lipids is an important advantage for lipid utilization by these invertebrates because hydrolysis of long-chain TAG provides essential fatty acids, such as linoleic and linolenic acids, as long as these are intended for $\beta$-oxidation.

Besides the physiological role of lipases in lipid catabolism, theses enzymes constitute one of the most important groups of biocatalyst for biotechnological applications, useful for improving food, detergents, pharmaceuticals, oleochemicals, textiles, cosmetics, and paper. The digestive gland of shrimp constitutes an alternative 
A. aegypti

I.scapularis

C.quinquefasciatus

$P$. vannamei

A. aegypti

I.scapularis

D. melanogaster

C. quinquefasciatus

$P$. vannamei

A. aegypti

I.scapularis

D. melanogaster

C. quinquefasciatus

$P$. vannamei

\section{A. aegypti}

I.scapularis

D.melanogaster

C.quinquefasciatus

$P$. vannamei

\author{
A. aegypti \\ I. scapularis \\ D. melanogaster \\ C.quinquefasciatus \\ P. vannamei
}

D. melanogaster

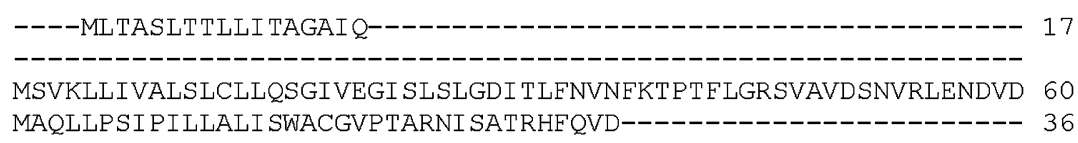
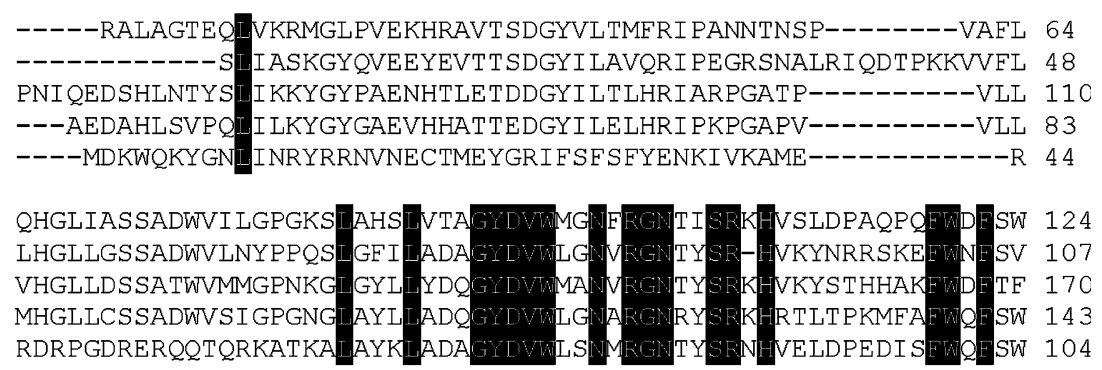
RDRPGDRERQQTQRKATKA AYKLADAGYDVWSWMEGNTYSFNHELDPEDISEWE SW 104
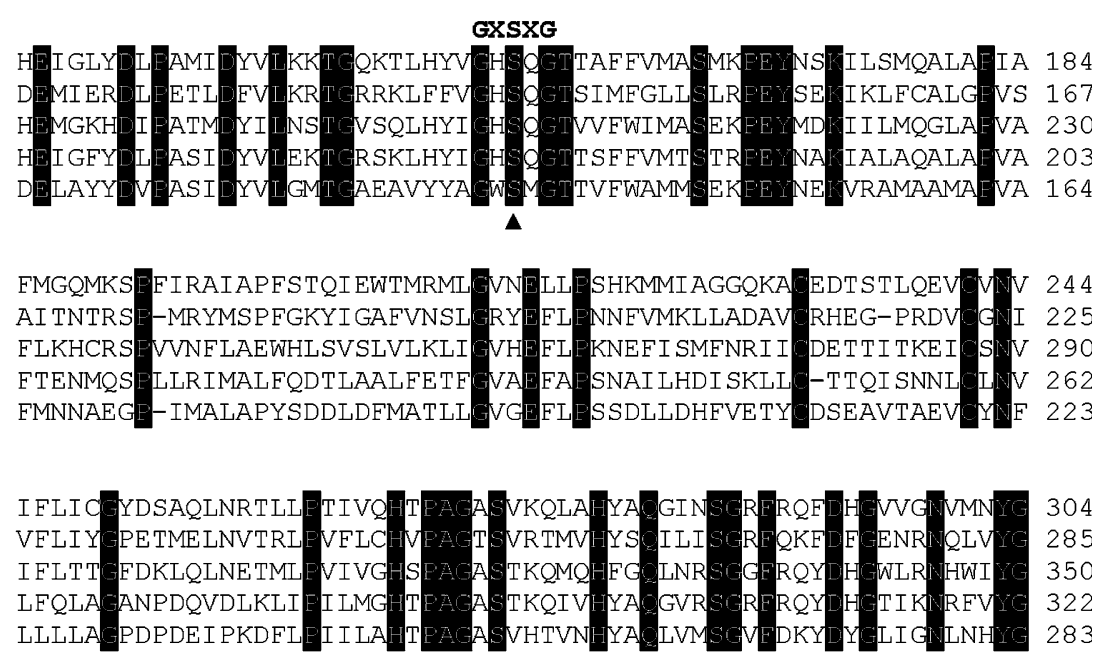

\author{
A. aegypti \\ I. scapularis \\ D. melanogaster \\ C. quinquefasciatus \\ $P$. vannamei
}

\author{
A. aegypti \\ I. scapularis \\ D. melanogaster \\ C. quinquefasciatus \\ $P$. vannamei
}

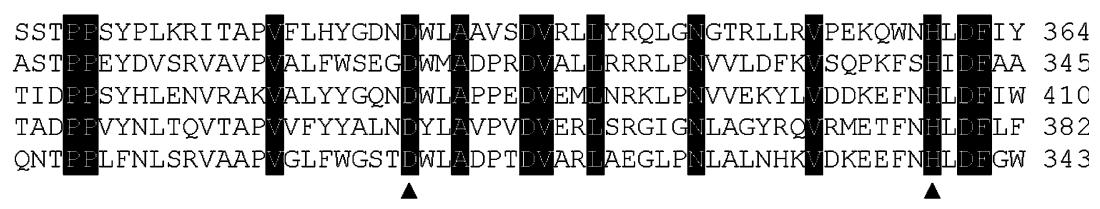

$\begin{array}{ll}\text { ATGAKSTLYNRVMDLMNRYNNAMPEKYRMEE } & 395 \\ \text { GI HAKA VYYEPMMKLMASYKSAGE------- } & 369 \\ \text { GI DARELLWDRMLEIMRNHENSI I------- } & 434 \\ \text { AKDVRTLLYEEI LGNVRRYGG---------- } & 403 \\ \text { GI HADELVYRHI LDF FANY------------ } & 362\end{array}$
Fig. 5 Multiple alignments of $p v l$ with other lipase proteins. Lipases from Culex quinquefasciatus (GenBank accession no. XP_001844302), Aedes aegypti (GenBank accession no. XP 001662499), Ixodes scapularis (GenBank accession no. EEC17018), and Drosophila melanogaster (GenBank accession no. NP_609418). Numbers on the

source of lipase that possesses a potential application in the oleochemical industry, since the kinetic values of PVL (Table 3) are in the range for most industrially relevant enzymes, $K_{\mathrm{m} \text {, app }}$ : between $10^{-1}$ and $10^{-5} \mathrm{M}$ (Fullbrook 1996). Our data also showed that PVL may be used in the detergent industry, since it can hydrolyze TAG as efficiently as commercial lipases from bacteria Mycobacterium tuberculosis and fungi Oryza sativa, with $K_{\mathrm{m} \text {, app }}=$ right indicate the amino acid position of different sequences. Identical amino acids are shaded in black. Shaded triangle indicates amino acid of catalytic triad: serine $(S)$, aspartic acid $(D)$, and histidine $(H)$. The consensus sequence is represented by GXSXG

7.57 and $6.71 \mathrm{mM}$, respectively (Deb et al. 2006; Bhardwaj et al. 2001).

\section{Conclusions}

The purification of a digestive lipase from midgut gland of the whiteleg shrimp P. vannamei and the full length of the 
lipase cDNA are described for the first time. It contributes to understanding of lipase of invertebrates, since the biochemical properties differ from mammalian organisms. Also, the results show a new source of lipolytic enzymes with potential biotechnological applications.

Acknowledgments C.R.P. is the recipient of a doctoral fellowship from Consejo Nacional de Ciencia y Tecnologia of Mexico.

\section{References}

Altschul SF, Madden TL, Schaffer AA, Zhang J, Zhang Z, Miller W, Lipman DJ (1997) Gapped BLAST and PSI-BLAST: a new generation of protein database search programs. Nucleic Acids Res 25:3389-3402

Arreguín-Espinosa R, Arreguín B, González C (2000) Purification and properties of a lipase from Cephaloleia presignis (Coleoptera, Chrysomelidae). Biotechnol Appl Biochem 31:239-244

Arrese EL, Wells MA (1994) Purification and properties of a phosphorylatable triacylglycerol lipase from the fat body of an insect Manduca sexta. J Lipid Res 35:1652-1660

Bhardwaj K, Raju A, Rajasekharan R (2001) Identification, purification, and characterization of a thermally stable lipase from rice Bran. A new member of the (Phospho) Lipase Family. J Plant Physiol 127:1728-1738

Borgstrom B, Donner J (1976) Interactions of pancreatic lipase with bile salts and dodecyl sulfate. J Lipid Res 17:491-497

Bradford MM (1976) A rapid and sensitive method for the quantification of microgram quantities of protein utilizing the principle of protein dye binding. Anal Biochem 72:248-254

Buscá R, Pujana MA, Pognonec P, Auwerx J, Deeb SS, Reina M, Vilaró S (1995) Absence of N-glycosylation at asparagine 43 in human lipoprotein lipase induces its accumulation in the rough endoplasmatic reticulum and alters this cellular compartment. J Lipid Res 36:939-951

Dall W, Moriarty DJW (1983) Nutrition and digestion. In: Mantle LH (ed) The biology of Crustacea. Academic, New York and London

De Caro A, Figarella C, Amic J, Michel R, Guy O (1977) Human pancreatic lipase: a glycoprotein. Biochim Biophys Acta 490:411-419

Deb C, Daniel J, Sirakova TD, Abomoelak B, Dubey VS, Kolattukudy PE (2006) A novel lipase belonging to the hormonesensitive lipase family induced under starvation to utilize stored triacylglycerol in Mycobacterium tuberculosis. J Biol Chem 281:3866-3875

Del Monte A, Nolasco H, Forrellat A, Aragón C, García A, Díaz J, Carrillo O (2002) Evidencias de la presencia de lipasas en el hepatopáncreas de Litopenaeus schmitti. Memorias del Congreso Iberoamericano Virtual de Acuicultura CIVA. Zaragoza, España

Dugi KA, Dichek HL, Santamarina-Fojo S (1995) Human hepatic and liporpotein lipase: the loop covering the catalytic site mediates lipase substrate specificity. J Biol Chem 270:25396-25401

Forrellat Barrios A, Del Monte A, Estévez T, Boburg B, Nolasco H, Carrillo Farnés O (2004) Caracterización de lipasas en tres especies de camarones peneidos. Su importancia en la digestión. memorias del Congreso Iberoamericano Virtual de Acuicultura CIVA. Zaragoza, España

Fullbrook PD (1996) Practical applied kinetics. Stockton Press, New York

Gargouri Y, Julien R, Pieroni G, Verger R, Sarda L (1984) Studies on the inhibition of pancreatic and microbial lipases by soybean proteins. J Lipid Res 25:1214-1221
Gargouri Y, Chahinian H, Moreau H, Ransac S, Verger R (1991) Inactivation of pancreatic and gastric lipases by THL C12:0TNB: a kinetic study with emulsified tributyrin. Biochim Biophys Acta 1085:322-328

Gasteiger E, Gattiker A, Hoogland C, Ivanyi I, Appel RD, Bairoch A (2003) ExPASy: the proteomics server for in-depth protein knowledge and analysis. Nucleic Acids Res 31:3784-3788

Gonzalez-Baró MdR, Pollero RJ (1998) Fatty acid metabolism of Macrobrachium borellii: dietary origin of arachidonic and eicosapentaenoic acids. Comp Biochem Physiol 119A:747-752

González-Félix ML, Pérez-Velazquez M (2002) Current status of lipid nutrition of pacific white shrimp, Litopenaeus vannamei. Avances en Nutrición AcuícolaVI Memorias del VI Simposium Internacional de Nutrición Acuícola. Cancún, Quintana Roo, México: Cruz-Suárez, L.E., Ricque-Marie, D., Tapia-Salazar, M., GaxiolaCortés, M.G., Simoe, N

Grillo LAM, Majerowickz D, Gondim KC (2007) Lipid metabolism in Rhodnius prolixus (Hemiptera:Reduviidae): role of a midgut triacylglycerol-lipase. Insect Biochem Mol Biol 37:579-588

Hermoso J, Pignol D, Kerfelec B, Crenon I, Chapus C, Fontecilla Campos JC (1996) Lipase activation by nonionic detergents. J Biol Chem 271:18007-18016

Hide WA, Chan L, Hsiung LW (1992) Structure and evolution of the lipase superfamily. J Lipid Res 33:168-178

Holm C, Osterlund T, Laurell H, Contreras JA (2000) Molecular mechanism regulating hormone-sensitive lipase and lipolysis. Annu Rev Nutr 20:365-393

Jaeger K-E, Dijkstra BW, Colson C, Mv H, Misset O (1994) Bacterial lipases. FEMS Microbiol Rev 15:29-63

Laemmli UK (1970) Cleavage of structural proteins during the assembly of the head of bacteriophage T4. Nature 227:680-685

Lim C, Ako H, Brown CL, Hahn K (1997) Growth response and fatty acids composition of juvenile Litopenaeus vannamei fed different source of dietary lipids. Aquaculture 151:143-153

Loizzi RF, Peterson DR (1971) Lipolytic sites in crayfish hepatopancreas and correlation with the fine structure. Comp Biochem Physiol Part B 39:227-236

López-López S, Nolasco H, Vega Villasante F (2003) Characterization of digestive gland esterase lipase activity of juvenile redclaw crayfish Cherax quadricarinatus. Comp Biochem Physiol B 135:337-347

Lowe ME (1997) Molecular mechanism of rat and human pancreatic triglyceride lipases. J Nutr 127:549-557

Marcus PI, Talalay P (1956) Induction and purification of alpha and beta-hydroxysteroid dehydrogenases. J Biol Chem 218:661-674

Matsumura S, Matsuo M, Nishizuka Y (1976) Partial purification and characterization of a triacylglyceride lipase from pig adipose tissue. J Biol Chem 251:6267-6273

Merril CR, Washart KM (1998) Gel electrophoresis of proteins: a practical approach. Oxford University Press, New York

Miled N, Canaan S, Dupuis L, Roussel A, Rivière M, Carrière F, de Caro A, Cambillau C, Verger R (2000) Digestive lipases: from three-dimensional structure to physiology. Biochimie 82:973-986

Moreau H, Abergel C, Carrière F, Ferrato F, Fontecilla-Camps JC, Cambillau C, Verger R (1992) Isoform purification of gastric lipases: towards crystallization. J Mol Biol 225:147-153

Mrdakovic M, Lazarevic J, Peric-Mataruga V, Ilijin L, Vlahovic M (2008) Partial characterization of a lipase from gypsy moth (Lymantria dispar L.) larval midgut. Folia Biol (Cracow) 56:103-110

Nayak J, Nair PGV, Mathew S, Ammu K (2004) A study on the intestinal lipase of Indian major carp Labeo rohita. Asian Fisch Sci 17:333-340

Ollis DL, Cheah E, Cygler M, Dijkstra B, Frolow F, Franken SM, Harel M, Remington SJ, Silman I, Schrag J, Sussman J (1992) The $\alpha / \beta$ hydrolase fold. Protein Eng 5:197-211 
Park J, Soon-Yeong C, Suk-Jung C (2008) Purification and characterization of hepatic lipase from Todarodes pacificus. BMB Rep 41:254-258

Prim N, Sánchez M, Ruiz C, Pastor FIJ, Diaz P (2003) Use of methyllumbeliferyl-derivate substrates for lipase activity characterization. J Mol Catal B Enzym 22:339-346

Rathelot J, Julien R, Bosc-Bierne I, Gargouri Y, Canioni PLS (1981) Horse pancreatic lipase interaction with colipase from various species. Biochimie 63:227-234

Roussel A, Canaan S, Egloff M-P, Riviére M, Dupuis L, Verger R, Cambillau C (1999) Crystal structure of human gastric lipase and model of lysosomal acid lipase, two lipolytic enzymes of medical interest. J Biol Chem 274:16995-17002

Shahani KM, Khan IM, Chandan RC (1976) Bovine pancreatic lipase. I. Isolation, homogenity, and characterization. J Dairy Sci 59:369-375

Slim C, Ahmed F, Nabil M, Heykel T, Hafedh M, Youssef G (2007) Crab digestive lipase acting at high temperature: purification and biochemical characterization. Biochimie 89:1012-1018

Stauffer C (1989) Enzyme assays for food scientist. New York.
Sukarno TK, Hatano M, Sakurai Y (1996) Lipase from neon flying squid hepatopancreas: purification and properties. Food Chem 57:515-521

Thompson JD, Higgins DG, Gibson TJ (1994) CLUSTAL W: improving the sensitivity of progressive multiple sequence alignment through sequence weighting, position-specific gap penalties and weigh matrix choice. Nucleic Acids Res 22:46734680

Thornton DJ, Carlstedt I, Sheehan JK (1994) Identification of glycoproteins on nitrocellulose membranes and gels. In: Walker JM (ed) Methods mol biol. Humana Press, Totowa, NJ

Versaw WK, Cuppert SL, Winter DD, Williams LE (1989) An improved colorimetric assay for bacterial lipase in nonfat dry milk. J Food Sci 54:1557-1558

Zouari N, Miled N, Cherif S, Mejdoub H, Gargouri Y (2005) Purification and characterization of a novel lipase from the digestive glands of a primitive animal: the scorpion. Biochim Biophys Acta 1726:67-74 